\title{
REGIONAL COOPERATION IN THE WESTERN BALKANS - A KEY TO INTEGRATION INTO THE EUROPEAN UNION
}

\begin{abstract}
Antonija Petričušić*
Summary: Impaired interethnic relations in the Western Balkan countries and the absence of multicultural policies proved to be major obstacles to stability, security and democracy in the 1990s. In attempting to identify what the security implications for enlargement are, the author argues that the EU should develop specific policies towards countries with a higher risk of ethnic tensions (e.g. Bosnia-Herzegovina) than those with no apparent potential for conflicts to re-emerge (e.g. Croatia). Further on, having claimed that the unresolved status of Kosovo and Bosnia-Herzegovina might have an impact on stability in the region, the author argues that, despite the EU's advocacy of an individual approach towards applicant states, the Union's relations with the Western Balkans will probably remain characterised by a more regional approach, in terms both of commonlyused patterns of accession (applying the same criteria and assessing achievements via the Stabilization and Association Process) and of the EU's insistence on regional cooperation. The necessity of regional cooperation in the Western Balkans is emphasised, and the political, economic and social problems common to all countries in the region are highlighted. Finally, the author concludes that the EU's insistence on regional cooperation in the region should be viewed as an incentive to addressing cross-boundary issues, and not as a threat that individual accession could be obstructed.
\end{abstract}

\section{Introduction and Basic Hypotheses}

Any kind of cooperation between states should enhance the security and stability among them. The example of the European Union (hereinafter: EU) is often pointed out as an undertaking that maintains peace among its member states. ${ }^{1}$ The unification of Europe will not be complete until the EU

\footnotetext{
1* Antonija Petričušić, MA, research fellow at the Institute for International Relations, Zagreb, Croatia. The author would like to thank Alexandra Letts and Leonhard Voltmer for their insightful comments on the draft of the paper. The first draft of the paper was prepared for presentation at the International Seminar "Advanced Issues of European Law", Inter University Centre, Dubrovnik, Croatia, 29 February - 7 March, 2004.

Ove Juul Jørgensen, The Enlargement Process: The Path to a Peaceful and Prosperous Europe, http://jpn.cec.eu.int/
} 
includes the region of the Western Balkans ${ }^{2}$, affected in the recent past by interethnic conflicts. Moreover, the prospective enlargement of the EU into the Western Balkans is perceived as the EU's contribution to security and stability in the region. Apart from playing a role in ending ethnic conflicts in the Balkans, the EU (together with other international organisations) still assures internal security in two Western Balkan countries in which NATO troops have been deployed (Bosnia and Herzegovina and in the Province of Kosovo of Serbia and Montenegro). ${ }^{3}$ Furthermore, it is very likely that the candidate status recently granted to one of the region's countries would bring stability not only to the country itself but also to the broader region. In addition, reconstruction and state building are mostly financed by the EU countries. ${ }^{4}$ The prospect is that it will become a development instrument, since the hope of accession has enhanced democratisation policies in the countries of the region, and has contributed to the undertaking of necessary transformations in domestic policies. ${ }^{5}$

\footnotetext{
${ }^{2}$ For the purposes of this paper, the Western Balkans refers to the region comprising the five Southeastern European countries involved in the EU Stabilisation and Association Process: Albania, Bosnia and Herzegovina, Croatia, Serbia and Montenegro and the Former Yugoslav Republic of Macedonia.

${ }^{3}$ Ethnic conflict contributed to redefining the relationship between the EU and the US. Only then did the EU start to design its own common foreign and security policy, independently of NATO. For example, $80 \%$ of approximately 50,000 NATO soldiers deployed in the Balkans are members of European armies. See Sophia Clement, The Balkans and Beyond: the European Perspective on Future Regional Stability, East European Studies/West European Studies p. 65-69, http://wwics.si.edu/ees/special/ 2000/clemen.pdf. The first European Union Police Mission (EUMP) was launched in Bosnia and Herzegovina in January 2003, taking over a task previously executed by the United Nation's International Police task Force (IPTF) and establishing for the first time a uniform EU police force. See also Adam Daniel Rotfeld (Ed.), The New Security Dimensions in Europe after the NATO and EU Enlargements (2001) Stockholm International Peace Research Institute.

${ }^{4}$ The EU countries provide the largest part of the financial assistance for development and reconstruction projects. See Economic Reconstruction and Development in South East Europe, http://www.seerecon.org/

${ }^{5}$ Vladimir Gligorov, Mario Holzner, Michael Landesmann, Prospects for Further (South) Eastern EU Enlargement: from Divergence to Convergence? (2003) 296 Research Report of the Vienna Institute for International Economic Studies. See also Samuel Huntington, Third Wave: Democratization in the Late Twentieth Century (1991) Norman: University of Oklahoma Press. See also Othon Anastasakis, EU Democracy Building in South-Eastern Europe: Is There a Contribution to the Democratisation Process?, http://www.qub.ac.uk/ies/events/confenlarg/ana.pdf. See also Leeda Demetropoulou, Europe and the Balkans: Membership Aspiration, EU Involvement and Europeanization Capacity in South Eastern Europe (2002) 2-3 Vol. III Southeast European Politics Online, p. $87-106$
} 
The Western Balkans is perceived as a region of weak states that still needs international support. ${ }^{6}$ In the past decade all the countries of the region have experienced a period of transition and ethnic conflict with a decline in the standard of living and a slowing of economic growth; yet they have achieved different levels of democratisation and are heterogeneous in their economic growth. ${ }^{7}$ There are also differences regarding their status and "distance" from the Union. Deteriorating interethnic relations within countries and an absence of multicultural policies have proven to be a major obstacle for stability, security and democracy in the region. On the basis of the existing policy developed to encourage EU enlargement into the Western Balkans, this paper argues that the only fair approach the EU could have accepted was a differentiated approach towards countries with a higher risk of ethnic tensions, e.g. Kosovo and Bosnia-Herzegovina, and those countries with low or no potential for the re-emergence of conflicts (e.g. Croatia). The paper will specifically argue that keeping the status of Kosovo unresolved, and carrying over an international co-governance in Bosnia and Herzegovina, might have a negative impact on the stability of the region that could eventually influence the speed of accession of neighbouring countries.

The paper will proceed in three parts. The first part will give a chronological overview of the recent EU policies vis-à-vis the Western Balkan states, from a humanitarian role at the beginning of the $1990 \mathrm{~s}$, through the involvement of the states of the region in Community programmes and institutions, to the introduction of accession negotiations with one of these countries in 2005. The second part of the paper will argue that even though the EU advocates a strictly individual approach towards potential applicants, a regional strategy will influence its demeanour in the Western Balkans, both through the commonly used patterns for accession, and through the EU's insistence on regional cooperation. The paper will then explore whether some countries risk being deprived of accession as a consequence of the security situation in their neighbouring countries. Finally, in the third part, the paper will examine the need for regional cooperation in the Western Balkans, pointing

\footnotetext{
6 Wim van Meurs (Ed.), Prospects and Risks Beyond EU Enlargement, Southeastern Europe: Weak States and Strong International Support (2003) Opladen: Leske \& Budrich. Laura Silber, Bush Has Neglected the Balkans For Too Long. A ticking time bomb. Article in the International Herald Tribune,13 January 2004.

${ }^{7}$ World Bank experts point toward poverty, unemployment, social cohesion and inadequate governance as common challenges faced by the region. See The World Bank Policy Research Working Paper, http://www.wds.worldbank.org/
} 
out that political, economic and social problems are common to all countries in the region. For this reason, the paper will argue that the insistence of the EU on regional cooperation should be interpreted as a call from the EU to the Western Balkan countries to address cross-boundary issues jointly, rather than as an obstacle to individual accession. The theoretical framework of the paper will apply the postulates of two aspects of liberal theory in international relations which in general advocates cooperation among states as a means of pursuing common interests. Applying the hypotheses of liberal internationalism and of neoliberal institutionalism, the paper will assert that the regional approach of the EU towards the Western Balkans as a region aims at the creation of transnational economies and the development of cooperation among states, by extending EU principles, policies and decision-making procedures. The paper will try to prove that regional cooperation and the establishment of free trade and economic exchange within the region could serve as a road to long-lasting peace, which is the goal of both the EU and the Western Balkan states.

\section{The European Union's Initiatives for South East Europe}

Cooperation among the EU and non-member states intensified considerably in the 1990s when the European Community opted to develop "contractual" relations with the applicant countries in Central and Eastern Europe. "Europe Agreements" were concluded with eight Central and Eastern European (CEE) countries ${ }^{8}$ and "Partnership and Cooperation Agreements" were signed with ten other countries that emerged from the former Soviet Union. $^{9}$ The Copenhagen Criteria for Central and Eastern European were designed in 1993 for countries wishing to join the EU. ${ }^{10}$ The EU announced that those pre-accession strategies would be eventually applied to all other states seeking accession to the EU. According to these criteria, a candidate country has to achieve stable democratic institutions, the rule of law, human

\footnotetext{
${ }^{8}$ Europe Agreements were concluded with Bulgaria, Estonia, Lithuania, Latvia, Poland, Romania, Slovakia, Slovenia, the Czech Republic and Hungary.

${ }^{9}$ Partnership and Cooperation Agreements were signed with Armenia, Azerbaijan, Belarus, Georgia, Kazakhstan, Kyrgyzstan, Moldova, Russia, Ukraine and Uzbekistan.

10 The European Union met at Copenhagen, Denmark in June 1993 with the intention of deliberating upon the issue of enlargement. Deciding to encourage the enlargement of the organisation, the EU agreed that "the associated countries in Central and Eastern Europe that so desire shall become members of the European Union after they achieve certain prerequisites in both a political and economic sphere. The European Council envisaged that the accession would take place as soon as an associated country was able to assume the obligations of membership by satisfying the economic and political conditions required.
} 
rights and respect for and protection of minorities. Moreover, stable institutions are needed to guarantee the implementation of the political criteria necessary for accession. The economic criteria require the existence of a functioning market economy and the capacity to withstand competitive pressures and market forces within the EU. The Copenhagen Criteria also established the obligation of the candidate country to create the conditions for its integration through the adjustment of its administrative structures, so that European Community legislation transposed into national legislation is implemented effectively through appropriate administrative and judicial structures.

In the early 1990s, the main area of EU involvement in the Western Balkans was of a humanitarian nature. The EU adopted a regional approach towards Southeastern European countries (hereinafter: SEE), whereby the main aim was to achieve basic stability and prosperity for the region as a whole. At that time, the region had been witnessing a chain of violent interethnic conflicts, so stability was obviously the minimum condition for further cooperation with the EU. The EU's first initiative to stabilise SEE was launched in December 1996. Known as the Royaumont Process, its aim was to support the implementation of the Dayton Peace Agreements. ${ }^{11}$ In 1997 the EU was still opting for the regional approach, establishing political and economic conditions as a prerequisite for bilateral relations with the five countries of the region. These conditions included respect for democratic principles, human rights and the rule of law, minority protection, market economy reforms and regional cooperation. In 1999, the EU encouraged reforms in the region which were meant to serve as pre-conditions for accession into the EU. It became apparent that the countries in the region needed to establish bilateral and multilateral relationships among themselves, and therefore the EU attempted to launch "a regional multilateral tool" 12 for the region: the Stability Pact. Launched in 1999, the Stability Pact was an initiative that drew together the EU and some other partner states with the aim of bringing peace, stability and economic development to the Balkans. ${ }^{13}$ The Pact has brought about a high degree of

\footnotetext{
${ }^{11}$ The Royaumont Process originally focused on promoting regional projects in the field of civil society, culture and human rights. It now advocates inter-parliamentary relations under the Stability Pact.

12 Vesna Bojicic-Dzelilovic, Othon Anastasakis, Balkan Regional Cooperation and European Integration (2002) The Hellenic Observatory, LSE, London, http://www.lse.ac.uk/_

13 The Stability Pact lays down a framework for cooperation between the European Union, the European Commission, the United States, Russia, Japan, Southeastern European countries, Turkey and other countries, including regional and international organisations
} 
cooperation among the Balkan countries, by promoting self-help aimed at ending dependency on donor countries. Chairman Erhard Busek claims that the Pact's accomplishments were more noteworthy "than most people in the region realise:" 14 under the pact, twenty-one free-trade agreements were concluded within the region. However, it could not meet all the goals required for the stabilisation of the region and a new approach was needed in order to address adequately the issues in the Western Balkans.

A cornerstone in the EU's approach to the Western Balkans after the postKosovo crisis was the introduction of the Stabilisation and Association process (SAp). This process promotes stability within the region and facilitates a closer association of the Western Balkan countries with the EU, and ultimately assists countries in their preparation for EU membership. The EU's General Affairs Council of May 2002 stated that "[t]he speed with which each country moves through the different stages of the SAp, taking ownership of the process, depends on the increasing ability to take on the obligations flowing from an ever closer association with the EU as well as compliance with the conditionality policy." However, some scholars have pointed out that the SAp has not been adequately and "cleverly sold to the people in the region as a process leading clearly to accession." ${ }^{15}$ In 2000, a new EU financial instrument "Community Assistance for Reconstruction, Development and Stabilisation" (CARDS) was set up. The CARDS initiative is a financial instrument used to manage EU assistance to SAp countries. ${ }^{16}$

The first Summit that brought together EU officials and leaders of the Western Balkan countries in Zagreb in November 2000 introduced a change in the EU approach towards the potential accession candidates of the Western Balkans. Whilst formally all Balkan countries were accepted as potential EU accession candidates, actual candidate status would depend on the intended implementation of reforms. ${ }^{17}$ For that reason, assistance and

and international financing institutions.

${ }^{14}$ Interview with Erhard Busek, Frankfurter Allgemeine Zeitung, 18 May 2004.

${ }^{15}$ Othon Anastasakis, Dimitar Bechev, EU Conditionality in South East Europe: Bringing Commitment to the Process, http://www.cespi.it/

${ }^{16}$ The allocation of funds by CARDS in 2003 was as follows: $€ 46.5$ million for Albania, $€$ 63 million for $\mathrm{BiH}, € 62$ million for Croatia, $€ 38.5$ million for FYROM, $€ 13.5$ million for Montenegro, $€ 229$ million for Serbia, $€ 49$ million for Kosovo. See http://europa.eu.int/

${ }^{17}$ The Declaration of the Zagreb Summit of European Union member-states and countries covered by the Stabilisation and Association Process, 24 November 2000, at http://europa.eu.int/ 
contractual relations with the Western Balkan countries have to be flexible and adapted to the specific conditions and needs of each individual country. The Copenhagen Council in December 2002 confirmed the European perspective of the five countries of the Western Balkans, and underlined the Union's determination to support their efforts - as potential candidates - to move closer to the European Union. The European Commission has also stated that "countries meeting the conditions should continue to be supported in a tangible way in progressing towards Europe." 18 Effective conditionality, according to the Commission, needs to be "complemented by effective support and advice on how to make necessary reforms." 19 The Thessaloniki Council, held in June 2003, encompassed the Second EUWestern Balkans Summit. On this occasion, the EU opened the Community programmes to the SAp countries along the lines established for the participation of CEE candidate countries. ${ }^{20}$ Declaring the EU's aim to make the Balkans an integral part of a unified Europe, the Thessaloniki summit confirmed that the "regatta principle" would be applied in the examination of each individual country's performance. This confirmed that the EU still regarded the region as a whole; nevertheless each country was given a chance to be rewarded individually for its progress. In other words, the progress of each country would depend on the ability and political will to introduce the necessary reforms and to implement and respect generally accepted rules and standards. Acknowledging the individual component of the enlargement, the countries of the region committed themselves at the Thessaloniki Summit to enhanced regional cooperation and the promotion of a series of specific objectives and initiatives.

The individual modality of the SAp is executed through the Stabilisation and Association Agreements (SAA) that were meant to be signed in due course between the EU and each of the Western Balkan countries. SAAs provide the possibility for each country of the region to move at its own pace towards meeting the demands of EU integration. The political significance of the SAA lies in the fact that it grants to the signatory party potential candidate status, thus offering the key to its EU accession. The Agreement is signed between a potential applicant state and the European Communities that are represented by the Commissioner for External Relations, together with the foreign ministers of all member states of the

\footnotetext{
${ }^{18}$ Report from the Commission. The Stabilisation and Association Process for South East Europe, Second Annual Report 2002, http://www.emins.org/

${ }^{19}$ Ibid.

20 Thessaloniki Agenda for the Western Balkans: moving towards European integration, Thessaloniki, 16 June 2003, at http://europa.eu.int/
} 
EU. The SAA is seen as an entry strategy, and as the introduction of European values, principles and standards to the associated country.

The regional cooperation approach has been used for accession negotiations with CEE countries. ${ }^{21}$ Besides cooperation amongst states and their regions, the general idea behind the EU integration process is the "cohesion policy" pursued within the Union that aspires to overcome economic differences among the EU's regions and countries. ${ }^{22}$ This policy is implemented through programmes that require cross-border cooperation among member states. ${ }^{23}$ Naturally, Western Balkan countries could also benefit from drawing on the experience of the new member states and their transition and pre-accession preparations. For that reason, they are not only encouraged to increase cooperation within the region, but also with EU members. ${ }^{24}$ An example of regional cooperation, which could serve as a model for the Western Balkan countries, is the Visegrád group: an initiative that gathered four countries of the Central European region (the Czech Republic, Hungary, Poland and Slovakia) with the common goal of cooperating in a number of fields of common interest for European integration. The cooperation that emerged from the mutual efforts towards European integration identified not only this as a common goal, but also the similarity of transitional changes in all countries with a "traditional, historically shaped system of mutual contacts, cultural and spiritual heritage and common roots of religious traditions." 25 All four countries became members of the EU on 1 May 2004, but

\footnotetext{
${ }^{21}$ Kyriaki Topidi, The Limits of EU Conditionality: Minority Rights in Slovakia (2003) 1 Journal on Ethnopolitics and Minority Issues in Europe, http://www.ecmi.de/jemie/

${ }^{22}$ European Stability Initiative. The Road to Thessaloniki: Cohesion and the Western Balkans, http://www.esiweb.org/. See also Marjorie Jouen, James W. Scott et al., Is the New Europe Inventing Itself in its Margins? Cross-Border and Transnational Cooperation, Notre Europe (2001) http://www.cor.eu.int/

${ }^{23}$ Under the European Regional Development Fund several initiatives were launched intending to strengthen economic and social cohesion throughout the EU. The Interreg III programme, for example, fosters balanced development through cross-border, transnational and interregional cooperation. See http://europa.eu.int/comm/regional_policy/interreg3/ index_en.htm.

${ }^{24}$ See, for example, the Third Annual Report of the Stabilisation and Association Process for South East Europe, $\operatorname{COM}(2004)$ 202/2 final, http://europa.eu.int/comm/external relations/see/sap/rep3/strat_pap.pdf

${ }^{25}$ Declaration on the cooperation between the Czech and Slovak Federal Republic, the Republic of Poland and the Republic of Hungary on the road to European integration, http://www.visegradgroup.org/
} 
nevertheless have declared their intention to maintain regional cooperation with each other. ${ }^{26}$

\section{$\underline{\text { Uniform Conditions applied in Diverse Realities }}$}

Neoliberalism explains the expansion impetus of institutions by reason of the organisation's gain when expanding "its principles, norms, rules and decision-making procedures over a larger set of states in order to better address specific issue-areas. ${ }^{27}$ The EU enlargement in May 2004 stimulates the countries remaining at the EU's doorstep. However, the Western Balkan countries did not start their approach towards the EU simultaneously: while Croatia $^{28}$ and Macedonia ${ }^{29}$ have already submitted applications for EU membership, some countries in the region that still face security problems are far from making the application. Furthermore, nationalistic policies, one of the main concerns of the international community that slows down the integration of the Western Balkans, are not being removed equally quickly in all of the region's countries. After the November 2003 election in Serbia, when the radical party obtained a relative majority, the High Representative in Bosnia and Herzegovina argued that for Serbia "the pull of the myth of nationalism remains stronger than the pull of Europe." 30 The nationalist orientation of any country in the region would constitute an impediment for good neighbourly relations, and this could block regional cooperation.

In the following paragraphs, the individual approach of the EU towards each of the Western Balkan countries will be examined, and consideration given to whether the security situation has actual implications on enlargement.

\section{Croatia}

\footnotetext{
${ }^{26}$ Substantive elements of the agreement include cooperation in a wide range of issues, including cross-border cooperation. See the Contents of Visegrád cooperation approved by the Prime Ministers' summit, Bratislava, 14 May, 1999, http://www.visegradgroup.org/

${ }^{27}$ Stephen Krasner (Ed.), International Regimes (1982) Ithaca: Cornell University Press

${ }^{28}$ The Republic of Croatia was the first of the Western Balkans countries to submit an application for EU membership on 21 February 2003 and received EU candidate status in June 2004.

${ }^{29}$ Macedonia officially handed in the application for EU membership on February 26, 2004.

${ }^{30}$ Paddy Ashdown, the High Representative in Bosnia and Herzegovina in an interview for the BBC, 15 February, 2004
} 
Croatia is a country whose official policies no longer manifest nationalistic features and whose economy outperforms that all other Balkan countries. It has made several internal legislative amendments required by the EU in order to achieve candidate status. Certain human and minority rights issues (such as the process of return of refugees of ethnic Serb origin and the restitution of their property by the end of 2004) as well as cooperation with the International Criminal Tribunal for the Former Yugoslavia improved after the change of government in 2000. The current government, elected in 2003, continues to meet the criteria for candidate status. This good record has been recognised and has encouraged negotiations for accession to the European Union. ${ }^{31}$ In fact, Croatia's candidate status was endorsed at the European Council summit in June 2004. It is hoped that the Croatian success in approaching the accession negotiations will encourage the other Balkan countries to intensify their progress in fulfilling EU conditionality principles, thus eventually leading them to achieve candidate status. The country optimistically aspired to join the EU in 2007, together with Romania and Bulgaria, but the postponement of the accession talks has made this plan unlikely and the government at the moment proclaims that the country could become an EU member by 2009. The regional approach naturally remains an essential element of EU policy towards the new candidate state which was urged "to continue to make a strong contribution to the development of closer regional cooperation." ${ }^{\prime 32}$

\section{Bosnia and Herzegovina}

The weak states $^{33}$ of the Western Balkans have been stabilised through a number of internationally brokered peace agreements. In the same way, the current (quasi-)stability is maintained by the presence of international peacekeeping forces. The Dayton Peace Accords ${ }^{34}$ of November 1995 ended ethnic conflicts in Croatia and in Bosnia and Herzegovina (hereinafter:

\footnotetext{
${ }^{31}$ The European Commission's Opinion on the Application of Croatia for Membership of the European Union, http://europa.eu.int/comm/external_relations/see/sap/rep3/cr_croat. pdf

32 Presidency Conclusions of the European Council, Brussels, 17 and 18 June 2004, http://www.ue2004.ie/templates/document_file.asp?id=19366, p. 8

33 A weak state is defined as one with inefficient institutions and which is unable or unwilling to enforce rules or to implement consistent policies. Weak states constitute the main obstacle for the necessary democratisation processes in the region. See Wim van Meurs (Ed.), see n. 6

34 The General Framework Agreement for Peace in Bosnia and Herzegovina, http://www.ohr.int/
} 
$\mathrm{BiH})$, but the provisions of the peace agreement have kept $\mathrm{BiH}$ in a position of a quasi-protectorate, governed by both domestic institutions and the international community. ${ }^{35}$ Eight years after the signing of the Dayton Peace Accords, their provisions "prevent Bosnians from being citizens with equal rights throughout the country, favour nationalist parties, and make selfsustaining peace difficult to achieve", ${ }^{36}$ since the peace agreement "was designed to end the war in $\mathrm{BiH}$, not to build the country." 37 The October 2002 parliamentary elections re-established the power of the three nationalist parties that governed the country during the 1992-1995 conflict, with Bosnia remaining sharply divided along the lines of two entities (the Serb one and the Croat-Bosniak one). In reaction, some international organisations reduced or closed their offices, and, even though domestic authorities have been finally encouraged to assume national ownership, a real withdrawal strategy does not yet exist. ${ }^{38}$ The idea that has been present in public debates in $\mathrm{BiH}$ for some years now advocates that decisions on BiH's distribution of power and resources should not be made by the international community, but by the country's political elite. Some suggest

\footnotetext{
${ }^{35}$ All major international organisations participated in a post-war reconstruction and state building processes in Bosnia and Herzegovina. The Office of the High Representative mission is to oversee implementation of the civilian aspects of the Peace Agreement. The European Union is represented through the European Commission's Delegation to $\mathrm{BiH}$ and the European Union Police Mission (EUMP). The OSCE Mission to $\mathrm{BiH}$ is primarily engaged in education, democratisation and human rights. The Commission for Real Property Claims (CRPC) and the UN Refugee Agency (UNHCR) representation in $\mathrm{BiH}$ deal with the restitution of property and the return of refugees respectively. The Council of Europe $(\mathrm{CoE})$ office in $\mathrm{BiH}$ mostly assists in legal reform and in the improvement of freedom of expression and the media. Other international organs present in $\mathrm{BiH}$ are the United Nations Development Program (UNDP), the World Bank and the International Monetary Fund (IMF). The Stabilisation Force (SFOR) Mission's mandate is to provide a safe and secure environment in Bosnia and Herzegovina. The only organisation whose mandate has ended is the United Nations Mission to Bosnia and Herzegovina (UNMIBH). It was set up in 1995 to deal with law enforcement activities and police reform, and was ended on 31 December 2002.

${ }^{36}$ United States Institute of Peace Report, Bosnia's Next Five Years: Dayton and Beyond, http://www.usip.org/ See also ESI Report, Making Federalism Work - A Radical Proposal For Practical Reform, http://www.esiweb.org/

${ }^{37}$ Adrian Pop, Security: from Powder Keg to Cooperation, in Wim van Meurs (Ed.), see n. 6 (p. 121)

38 A recent joint declaration signed by all the parties represented in the $\mathrm{BiH}$ House of Representatives pledging their readiness to find consensus in order to achieve membership of the European Union and NATO's Partnership for Peace offers some hope that Bosnian politicians are more willing to take greater initiative in governing their country. See press release at the site of the High Representative, 18 February, 2004, http:/www.ohr.int/
} 
that in order to undertake necessary reforms, $\mathrm{BiH}$ should become a federal state comprising twelve federal units. ${ }^{39}$

\section{Serbia and Montenegro}

The EU played an active role in the creation of a looser federation between Serbia and Montenegro (hereinafter: SiM) in February 2003, determined to block Montenegrin independence and keep the two republics together. ${ }^{40}$ The population of Montenegro is sharply divided between those who back independence, and those in favour of union with Serbia. Serbia is economically as well as politically far from fulfilling the conditions for accession. However, the political leaders of both republics promote EU membership and good relations with the other Balkan countries as political priorities. An example of the efforts successfully concluded is the resolution of the dispute between Croatia and SiM for the Prevlaka peninsula, a strategic area at the southernmost tip of Croatian territory. Furthermore, the abolition of visa requirements, the conclusion of a free trade agreement and the mutual payment of pensions were agreed upon by the two neighbouring countries. These and other achievements were fully acknowledged by the international community, and were eventually evaluated as an asset in the case of Croatia's application for EU membership.

Nevertheless, no matter how strong the economy of Serbia and Montenegro might become, it is hardly, if at all, conceivable that Serbia could join the EU without having solved the Kosovo problem. Kosovo, sometimes described as "the time bomb ticking under the Balkan body politics" ${ }^{41}$ with its blurred and undefined status, constitutes a Gordian knot, not only for the accession of SiM into the EU but also for the whole Balkan region. ${ }^{42}$ Apart from the status quo, which implies the long-lasting presence of the international community, there are three possible political solutions to this problem: the first would be to include Kosovo as a federated unit in the new federal union; the second would be the union of the Province of Kosovo with Albania, advocated by a minority of ethnic Albanians in

${ }^{39}$ See, for example, the report prepared by the European Stability Initiative: Making Federalism Work - A Radical Proposal for Practical Reform, http://www.esiweb.org/

${ }^{40}$ International Crisis Group (ICG) Report, Still Buying Time: Montenegro, Serbia and the European Union, http://www.reliefweb.int/

${ }^{41}$ Laura Silber, Bush Has Neglected the Balkans For Too Long. A ticking time bomb. Article in the International Herald Tribune, January 13, 2004

${ }^{42}$ Ylber Hysa, Kosovo: A Fragile Agenda of Democratization. In Wim van Meurs (Ed.), see n. 6 (p. 213-225) 
Kosovo; ${ }^{43}$ and the third would be to grant the status of independence, recognising the right to self-determination of the Albanian community in Kosovo. The last mentioned scenario would have no precedent in the recent history of SEE, since the principle of integrity of previously existing internal borders within the Socialist Federal Republic of Yugoslavia would be infringed. In addition to this, Macedonia, a neighbouring state to the Kosovo province, is determined not to recognise an independent Kosovo; it fears that it could stir up the secessionist claims of the Albanian minority that makes up one quarter of Macedonia's population.

The role of the international community will be crucial in finding the final status for the Province of Kosovo, and it should do so by taking into consideration how the decision will affect neighbouring countries. The preparation of the Kosovo protectorate for European integration is among the priorities of the mandate of the United Nations Interim Administration Mission in Kosovo (UNMIK) which administers the province. In spite of its engagements in Kosovo in the post-crisis reconstruction process, it seems that the EU and the greater international community still lack a clear vision for the future of the territory. Certain scholars envisaged that the resolution of Kosovo's status and that of the Balkans in general should be conceded to the EU, since neither the United Nations nor the United States treat the Balkans as one of their priorities. ${ }^{44}$ Following a violent upheaval in March 2004, it became apparent that a search for a solution regarding the status of Kosovo will be even more difficult than first believed. Although it is generally considered that resolving Kosovo's status would accelerate the region's integration into the EU, the Belgrade-Pristina direct dialogue is still in a very fragile phase. The document "Standards for Kosovo" launched in December 2003 by the international community foresees actions that have to be undertaken by the province's Provisional Institutions of SelfGovernment $(\mathrm{PISG})^{45}$ in order to decide upon the permanent future status of

\footnotetext{
43 ICG Report, Pan-Albanianism: How Big a Threat to Balkan Stability?, http://www. crisisweb.org/, p. 14

${ }^{44}$ Dusan Janjic, The Present Status of Kosovo Cannot Last Longer Than 2005, New Balkan Politics Journal, http://www.newbalkanpolitics.org.mk/, and Dieter Mahncke (Ed.), Old Frontiers - New Frontiers, The Challenge of Kosovo and its Implications for the European Union, http://www.euintegration.net/

45 The PISG comprise the Assembly, the President, the Government containing ten ministries, and the court system, while the UNMIK retains exclusive powers in the rule of law, security and property issues. See ICG Report, Two to Tango: An Agenda for the New Kosovo SRSG (2003) http://www.crisisweb.org/ -
} 
Kosovo. ${ }^{46}$ This document makes, inter alia, engagement in direct talks a precondition for the opening of the discussions for Kosovo's final status. Nonetheless, the UNMIK has received declarations that both parties involved in negotiations do back regional cooperation. It is expected that talks on the final status solution should start in 2005.

\section{Macedonia}

Even though it was the first country of the region to sign the SAp in 2000, Macedonia submitted its membership application only on March 22, 2004. The government had already presented a national programme for adjusting national legislation to the acquis, and strategies for a reform of the judiciary and the police were launched to meet the Copenhagen Criteria. The Ohrid peace agreement, ${ }^{47}$ signed on 13 August 2001, ended seven months of fighting between the ethnic Albanian rebels of the National Liberation Army (UCK) and Macedonian government forces in Macedonia. The prompt intervention of the international community in this case made unlikely "a repetition of the scenario of Bosnia and Herzegovina". ${ }^{48}$ Macedonian authorities have been warned that " $\mathrm{t}]$ he only road to Brussels runs through Ohrid", ${ }^{49}$ meaning that the implementation of the Ohrid peace agreement is the most important precondition for closer relations between the country and the EU. Consequently, the government decided on 16 December 2003 to undertake a concrete action plan for the implementation of the Agreement.

\section{Albania}

Albania is the poorest country in the region, and among the least economically developed European country. Even though it did not experience ethnic turmoil in the 1990s it depends on foreign financial support. The Country Strategy Paper for Albania recommends certain institutional, political and economic reforms that the country will have to

\footnotetext{
${ }^{46}$ The measures should improve the functioning of democratic institutions, the rule of law, the freedom of movement, return and reintegration, the enhancement of the economy, repossession of property rights, and dialogue with Belgrade. Eventually, fulfilment of these measures would decide whether the province is ready for talks on its future status after a review of the progress in the targets' implementation by mid-2005.

47 Framework Agreement concluded in Skopje on 13 August 2001, http://www.venice.coe.int/

48 see n. 37 , p. 123

${ }^{49}$ Interview with Javier Solana in "Dnevnik" of 7 February 2004, http://ue.eu.int/
} 
undertake in order to qualify for EU membership. ${ }^{50}$ In January 2004 the negotiations for a SAA between the EU and Albania were launched. The security threats that might endanger the stability of the Western Balkans in the case of Albania are incorporated in the political groups present in Kosovo and Albania which advocate the constitution of a greater Albania, annexing the territory of the Province of Kosovo and parts of Macedonia to Albania. ${ }^{51}$ In order to please Brussels, the Albanian president Alfred Moisiu declared that the country supports direct talks between Pristina and Belgrade in finding a solution for the status of Kosovo and promotes cooperation and stability in the region. ${ }^{52}$ Albanian political representatives took part in the unsuccessful first round of negotiations over the status of Kosovo held in Vienna in October 2003. It is not very likely that the official Albanian position in the negotiations would openly advocate independence for Kosovo.

\section{The Other Neighbouring Countries}

Two candidate countries neighbouring the Western Balkans, Bulgaria and Romania, have achieved neither sufficient economic progress nor a functioning market economy, which are the key preconditions for EU membership. Consequently, they remained outside the recent enlargement wave. ${ }^{53}$ However, the Commissioner for Enlargement, Günter Verheugen, stated that considerable progress has been made in the accession negotiations with Bulgaria and Romania and referred to the whole process encouragingly, describing their accession to the EU in 2007 as "realistic". ${ }^{4}$ Romania began official accession talks in February 2000 and has not yet closed all of the 30 chapters of negotiation, while Bulgaria, which started the accession negotiations in March 2000, has already done so. Bulgaria is technically ready for accession in 2007 , but the Commission might postpone it for one year if the already adopted reforms are not properly implemented. Even though both countries hope to be ready to join the EU in 2007, they accuse each other for the slow accession progress. Bulgaria, which is doing better economically, is particularly prone to make accusations that it is

\footnotetext{
${ }^{50}$ Community Strategy Paper for Albania, 2002-2006, http://www.europa.eu.int/

${ }^{51}$ International Crisis Group (ICG) Report, Pan-Albanianism: How Big a Threat to Balkan Stability?, http://www.crisisweb.org/, p. 14.

${ }^{52}$ Southeast European Times, 18 February 2004, http://www.balkantimes.com/

${ }^{53}$ The European Commission's Regular Report on Romania's progress towards accession, and the European Commission's Regular Report on Bulgaria's progress towards accession, 5 November 2003, http://europa.ed.int/

${ }^{54}$ Ibid.
} 
being dragged down by Romania's slow implementation of the acquis. ${ }^{55}$ Regardless of the disputes and mutual accusations, the countries' leaders realise that the only way to the EU is through cooperation, not only between themselves but also with the broader region. Taking this into consideration, Bulgaria's Foreign Minister has stated that "[a]n eventual suspension of Romania's [accession] talks would trigger a delay in the EU integration of the whole Balkan region." 56

Is there an Alternative to Regional Cooperation?

According to liberal internationalism - which finds in the EU itself a textbook example of inter-state cooperation - a transnational economic society of free commerce and industry links people across borders and thus enhances state interests in cooperation and peace. ${ }^{57}$ Regional cooperation is an integral part of the preparation for integration into European structures. ${ }^{58}$ The EU insists on improved relations between countries that were recent enemies, not only because it encourages and applauds economic development, but also as a guarantee of stability and security.

Even though the EU has often been criticised for insufficient engagement in the resolution of the conflicts that took place in the Western Balkans and the lack of a clear perspective regarding the membership of the Western Balkans region, the Union's efforts to contribute to the development of the Balkan region must be acknowledged. ${ }^{59}$ The EU in practice uses the prospect of integration as part of the "carrot and stick" method in conditioning financial aid for Western Balkan's stabilisation and development. The EU employs the argument of necessary compliance with EU standards whenever it wishes to foster local support for the government on issues that might be difficult to justify to the local electorate. At the same time, the EU expects all Western Balkan governments to upgrade their

\footnotetext{
${ }^{55}$ Viktor D. Bojkov, Disassociation through Integration - the Case of Bulgaria and EU Enlargement (2003) 1 Novi Pogledi p. 17-19

56 Article in the Bulgarian magazine "Novine", Bulgaria Throws Embattled Romania Lifeline en Route to EU, 14 February 2004, http://www.novinite.com/

57 See Stanley Hoffmann, The Crisis of Liberal Internationalism (1995) Foreign Policy, Spencer R. Weart, Never at War: Why Democracies Will Not Fight One Another (1998) New Haven: Yale University Press

${ }^{58}$ Communication from the Commission to the Council and the European Parliament, The Western Balkans and European Integration, http://europa.eu.int/comm/external relations/see/2003.pdf

${ }^{59}$ See n.15, p. 16. Sophia Clement, for example, claims that "Kosovo demonstrated the long-term economic, political and military consequences of the failure to address a crisis preventively". See Sophia Clement, n.3
} 
institutions and governance to European standards and to engage in mutual cooperation. Financial assistance for various economic and development programmes is often conditioned by the country's willingness to enter into bilateral relations with the five countries of the region. This is justifiable, since the regional cooperation introduced in SAp was based on the European Union model of integration and cooperation. The CARDS programme assists regional authorities in gearing up to the reforms required by the EU with $€ 197$ million in the period $2002-2004 .^{60}$

The individual component of the EU policy underlines that each country's contribution to achieving regional objectives will help to determine its readiness to take on the demands of full integration into the EU. However, the individual approach has been criticised by some scholars. Condemning the insufficient requirements for regional cooperation within the Stabilisation and Association agreements, they promote the idea that the EU should consider the region as a whole. ${ }^{61}$ Advocates for regional cooperation stress that the Western Balkans' "economic geography and specific historical legacies have important consequences for patterns of development, and that structural causes of underdevelopment can determine the fate of entire regions, be they old industrial centres or peripheral rural areas". ${ }^{62}$ Explaining that regional cooperation is very often "the outcome of the interplay between external/international factors and internal dynamics," ${ }^{63}$ Vesna Bojičić-Dželilovic and Othon Anastasakis argue that the international community has achieved insufficient results by way of pursuing regional strategies "which are not always consistent", ${ }^{64}$ mostly because the process of regional cooperation was imposed, and the local actors/elites were not properly included. Those scholars claim that it is crucial to have the support of the local elite since "the decision to engage in regional cooperation in a constructive manner ultimately rests on the willingness of the local elites to identify common and mutual interests and,

\footnotetext{
${ }^{60}$ The main areas of intervention funded by CARDS are the promotion of integrated border management, the promotion of democratic stabilisation, institution building, the development of regional infrastructure approaches, work in the field of higher education and vocational training (TEMPUS), SIGMA and Twinning.

${ }^{61}$ See United States Institute for Peace Special Report No. 54, De-Balkanizing the Balkans. Security and Stability in Southeastern Europe, http://www.usip.org/

62 European Stability Initiative, The Road to Thessaloniki: Cohesion and the Western Balkans, http://www.esiweb.org/

${ }^{63}$ See n. 12

64 Ibid.
} 
with outside help, translate them into workable initiatives with practical and beneficial results." ${ }^{\prime 65}$

For a long time, the Croatian political establishment feared that insistence on regional cooperation might set the country back into new state structures in the Balkans. Perhaps for that reason the government has been insisting on giving equal weight to regional cooperation and individual performances in the country's approach towards the EU. The former Minister for European Integration claimed, for example, that "coordinated regional initiatives are welcome, but an individual approach to the EU is a must." ${ }^{166}$ Croatian President Stipe Mesić stated that "progress in regional cooperation represents one of the criteria in play for assessing the speed of convergence of individual countries with the European Union, but Croatia does not want to be a prisoner of the region" ${ }^{67}$ nor wants "regional cooperation to become an end in itself." ${ }^{\prime \prime}$ A previous Croatian minister of foreign affairs, Miomir Žužul, bore witness to the country's commitment to regional cooperation in his address to the Permanent Council of the OSCE in February 2004, claiming that Croatia's objective is "to maintain and strengthen relations with $[\ldots]$ neighbouring countries and within the wider region." 69

Nevertheless, regional integration has much less political support throughout the region than integration into the European Union. At the same time, intra-regional trade remains low, at about $6 \%$ of the total trade of all five countries. ${ }^{70}$ Balkan economists tend to underestimate the importance of intra-regional trade, arguing that neighbouring countries are too poor to be of interest for investment or that neighbours constitute economic competition. Discrepancies in the economies of the Western Balkans are indeed severe. Croatia is the largest economy with a GDP of some $€ 23$ billion, accounting alone for nearly half of the region's GDP; the average

\footnotetext{
${ }^{65}$ Ibid.

${ }^{66}$ Neven Mimica at the conference "Forum for European Integration", Skopje, Macedonia, 15-16 March 2003, http://www.esiweb.org/

${ }^{67}$ Lecture of Stipe Mesic at Charles University, Czech Republic: Croatia - One Year After. There is no alternative to democracy and Europe, http://certik.ruk.cuni.cz/

68 Ibid.

${ }^{69}$ Address by Dr. Miomir Žužul, Minister of Foreign Affairs of the Republic of Croatia, at the 495th meeting of the OSCE Special Permanent Council, 16 February 2004, http://www.osce.org/

70 See the European Commission's Second Annual Report, The Stabilisation and Association Process for South East Europe, 2003, http://www.emins.org/
} 
per capita income is approximately $€ 5100$ in Croatia, while the average of all the other countries is about $€ 1350$. $^{71}$

Višnja Samardžija and Will Bartlett predict faster liberalisation in trade between the individual countries and the EU than between the countries in the region. ${ }^{72}$ Contrary to current practice, Liz Barrett advocates intraregional trade, and more particularly the creation of a Balkan single-market. Barrett highlights business as the driving force for a single market in the Balkans, claiming that cross-border business links would enhance economic gains "through higher levels of entrepreneurial activity and increased foreign investment". ${ }^{73}$ Trade integration of Western Balkan countries both with the EU and within the region itself has improved through the network of free trade agreements signed between the countries of the region under the auspices of the Stability Pact's working group on trade liberalisation. It is expected that those free trade agreements will not only boost intraregional trade, but also enhance production and increase competition.

The 2004 Annual Report of the SAp defines regional cooperation as "the natural way to tackle shared problems and to make further progress in important sectors". ${ }^{74}$ It endorses regional cooperation as an issue that goes hand in hand with the further development of the individual countries. The report indicates the common challenges that the Western Balkan countries face: the return of refugees, infrastructure and economic development and the fight against organised crime underlying the cross-border dimensions of the given issues. Sharing a similar history and facing similar transitional problems, the Western Balkans could benefit from an exchange of knowledge, new practices and skills achieved in the neighbouring countries.

\footnotetext{
${ }^{71}$ The population of the Western Balkans region is about 25 million people, and its economic size (GDP) is equivalent to some $€ 50$ billion. See Developing Regional Cooperation, http://www.emins.org/dokumenti/stabilisation-see.pdf. The World Bank's report reads that the GDP of SEE (also including, apart from the countries under study in this paper, Romania and Bulgaria) is $\$ 2,200$ per capita, roughly half the income level of the five Central European countries (Poland, Hungary, Czech Republic, Slovak Republic, and Slovenia), The World Bank Report, The road to stability and prosperity in South-Eastern Europe (2000) http://www.worldbank.org/

${ }^{72}$ Višnja Samardžija, Will Bartlett, The Reconstruction of South East Europe, the Stability Pact and the Role of the EU: an Overview (2000) 2 MOCT-MOST p. 245-263

${ }^{73} \mathrm{Liz}$ Barrett, Business in the Balkans: The case for cross-border cooperation, CER working paper (2002) http://www.cer.org.uk/

74 The Stabilisation and Association process for South East Europe, Third Annual Report $(\operatorname{COM}(2004) 202$ /2 final), Brussels, 30.3.2004, http://europa.eu.int/comm/external relations/see/sap/rep3/strat_pap.pdf
} 
The modernisation theory in developmental science puts forward economic and political developments as factors that promote the integration of ethnic groups in post-conflict societies. ${ }^{75}$ The promotion and strengthening of good neighbourly relations in the Balkans are demonstrated in both economic and political fields. Political measures that contribute to regional networking in South East Europe include the abolishment of the visa system, the accommodation of minorities and the commitment to regional cooperation among Croatia, Bosnia and Herzegovina and Serbia and Montenegro in resolving the issue of return of refugees and repossession of property. The Western Balkan is perceived as a region with porous borders and a gateway for criminal activities, illegal immigration, organised crime and, possibly, terrorist actions. ${ }^{76}$ For that reason, the EU insists upon law enforcement in the countries of the region, promoting cooperation in justice and home affairs, and making clear that regional political and institutional cooperation will improve the prospect of closer integration into the EU. The enhancement of economical regional cooperation in inter-state transport and trade integration, as well as compliance with the economic criteria of the EU, lay the foundations for economies to be able to catch up with the strong economies of the EU member states. Indeed, the business sector has made the first move towards the reestablishment of connections among the countries of the region. One example is Kosovo: "political dialogue between Serbs and Albanians remains stalled, trade between the two is booming". ${ }^{77}$

75 The modernisation theory, together with the neoliberal theory, belongs to the neoclassical theories of economic growth in the broader paradigms of development. Advocates of the modernisation theory assume that a linear process exists whereby developing countries progressively become industrialised. They furthermore consider that the industrialising experience of rich countries should serve as a good example for the developing ones. The rich countries have, according to the proponents of the theory, been successful in implementing the concept of modernity, which brings the blessings of progress in every sphere of human life. The main opponents to both modernisation theories and the neoliberal approach make the criticism that those theories fail to focus on the social and cultural needs inherent to development, and only look towards economic solutions. See W. W. Rostow, The Process of Economic Growth, Oxford: Oxford University Press, 1953. Samuel P. Huntington, Political Order in Changing Societies, New Haven, CT: Yale University Press, 1968. Thomas D. Lairson and David Skidmore, International Political Economy: The Struggles for Power and Wealth, New York: Harcourt Brace College Publishers, 1993. Ronald Inglehart, Modernization and Postmodernization: Cultural, Economic, and Political Change in 43 Societies, Princeton: Princeton University Press, 1997.

${ }^{76}$ On corruption and organised crime in South East Europe, see n. 37, p. 124-129

77 Tanja Matić, Altin Ahmeti, Kosovo: Trade Booms Between old Enemies (2004) 479 IWPR's Balkan Crisis Report, http:/www.iwpr.net/ 
Therefore, it seems that regional cooperation among the Western Balkans is a necessity that actually provides for mutual benefits. A country that opts for the other solution inevitably heads into economic and political isolation.

\section{$\underline{\text { Conclusion }}$}

The short-term goal of the EU for the Western Balkans was the stabilisation of the region and the prevention of new conflicts. The subsequent goal was to foster the development of economic, political and cultural ties within the region. Assuming that the EU will eventually integrate the Western Balkans, one of the hypotheses of this paper is that accession to the European Union will safeguard peace and stability, not only in the region but also in the European continent.

Stronger regional cooperation increases the prospects for the more rapid integration of the region into the EU. Some feared that regional cooperation would be a trap to keep the countries of the Western Balkans together without giving them the chance to prove their progress individually. However, this proved to be false when Croatia succeeded in gaining candidate status in June 2004. Nevertheless, the issue of support from the local elites for regional cooperation remains crucial, since they are the ones responsible for the implementation of the EU's conditionality policies.

The governing political establishments of the Western Balkan states consider that the only fair approach towards eventual EU enlargement is a fully flexible, multi-speed accession process, known also as the "regatta principle". It allows each of the Western Balkan countries to proceed at its own pace and to be assessed on its own merits. Countries will join when they are able to meet all the obligations inherent to membership and to accept compliance with the common European values and standards, as well as the acquis communautaire. For that reason, each country is motivated to accelerate necessary reforms. Highlighting the implications of Croatia's candidate status for other countries of the Western Balkans, the European Council emphasised that the advance of the individual countries of the region towards European integration will proceed in parallel with the regional approach, which remains an essential element of EU policy. Even though the individual approach is not inconsistent with the development of regional cooperation, it might be seen as an impediment to good neighbourly relations. Namely, by advocating an assessment of individual achievement, the individual approach promotes competition in economic and other areas. The individual approach also allows for the possibility that 
some countries might outperform others. However, for the time being it is hard to imagine that one of the Western Balkan countries could speed up in the accession process to such an extent that it would outrun Romania and Bulgaria. Finally, the argument in favour of an individual approach towards the Western Balkan countries might be found in the "contagion" effect of the neighbour's accession to the EU. The effects of the potential acceptance of one of the Western Balkan countries would probably be positive in the administrative, judicial and police sectors of its neighbouring countries, and hence consolidate the rule of law and the capacity of the state institutions in the whole region. 